\title{
Comparison of the impact of regional and North Atlantic atmospheric circulation on an aquatic ecosystem
}

\author{
Thorsten Blenckner ${ }^{1, *}$, Deliang Chen ${ }^{2}$ \\ ${ }^{1}$ Erken Laboratory, Department of Limnology, Evolution Biology Centre, Uppsala University, Norr Malma 4200, \\ 76173 Norrtälje, Sweden \\ ${ }^{2}$ Department of Earth Sciences, Göteborg University, Box 460, 40530 Göteborg, Sweden
}

\begin{abstract}
Atmospheric circulation is important in affecting surface climate and ecosystems. In this study, we compared the impact of North Atlantic and regional atmospheric circulation, as represented by the North Atlantic Oscillation (NAO) index and a set of regional circulation indices on local air and water temperature, ice phenology and the phytoplankton spring bloom in a Swedish lake. All these variables were significantly correlated to both circulation indices, except for the water temperature due to the insulation effects of ice and snow cover. These relationships were more powerful using the regional circulation indices, implying that the regional indices explained the variability of the lake variables with a higher power compared with the NAO index. Additionally, the application of regional indices allowed the determination of underlying processes. For example, the timing of the ice break-up could be explained with $73 \%$ by the regional index associated with total wind speed from January to March. This example suggests that regional circulation indices are very useful tools, in addition to global circulation, to improve the understanding of the interaction between ecosystem processes and climate.
\end{abstract}

KEY WORDS: Atmospheric circulation - NAO - Climate $\cdot$ Ice $\cdot$ Spring bloom $\cdot$ Lake ecosystems

Resale or republication not permitted without written consent of the publisher

\section{INTRODUCTION}

Atmospheric circulation is known to have a major impact on local climate (Kidson 1994) and thus partly accounts for its variability. So far several studies on local climate variability have focused on a circulation index that explains to a substantial proportion (up to $30 \%$ ) the interannual and interdecadal climate variations in a region ranging from the eastern seaboard of the US across the Atlantic to Central Asia: the North Atlantic Oscillation (NAO) (Hurrell 1995, 1996). It is a measure of the difference in sea-level pressure between the Azores high and the Iceland low (Hurrell 1995). A high, positive NAO index (NAOI) indicates mild and rainy winters, while low values accompany cold winters over Europe. The NAO has been found to influence local variables such as temperature (Plaut et al. 1995, Chen \& Hellström 1999), snowfall (Hartley \&
Keables 1998) and the timing of lake ice break-up (Livingstone 1999). Even at an organism level, an NAO signature is apparent, e.g. in plankton (Fromentin \& Planque 1996, Weyhenmeyer et al. 1999, Gerten \& Adrian 2000), macrofauna (Hagberg \& Tunberg 2000), plants (Post \& Stenseth 1999), amphibians and birds (Forchhammer et al. 1998), moose (Post \& Stenseth 1998) and wolf behaviour (Post et al. 1999). A review of this is given by Blenckner \& Hillebrand (2002).

However, more detailed information on local climate variability can be obtained from circulation indices, which are calculated over a smaller (regional) area (Lamb 1950), such as Scandinavia or the UK. Recently, Chen (2000) established such a set of regional circulation indices for Scandinavia on a monthly basis, based on a $5^{\circ}$ latitude $\times 10^{\circ}$ longitude grid-point dataset for the Northern Hemisphere (see for more details Chen 2000). A statistical model of these circulation indices 
has been found to explain up to $70 \%$ of the total variance in January air temperature for Sweden (Chen 2000). So far, only 1 study has compared these regional indices and the NAO impacts regarding the year-toyear variation of environmental variables; the regional circulation was found to explain $64 \%$ of the variance of Baltic Sea ice extent, while the NAO only explained $29 \%$ (Omstedt \& Chen 2001).

In this study, we employed a large-scale circulation index, the NAO, and a set of regional indices to examine their influence on a lake ecosystem from winter to summer. Earlier findings suggested a substantial impact of the NAO on winter ice cover and spring plankton dynamics (Livingstone 1999, Weyhenmeyer et al. 1999, George 2000, Gerten \& Adrian 2000, 2001). Winter is the period with the highest variation and change in the Northern Hemisphere (Meehl et al. 2000) and has therefore a potentially high impact on the ecosystem and on the following seasons in terms of water temperature (Gerten \& Adrian 2001) and summer phytoplankton biomass (Blenckner et al. 2002). So far, no studies of regional circulation indices on ecosystem responses, to the best knowledge of the authors, have been conducted. As the regional indices integrate the climate over Scandinavia with a higher spatial resolution compared to the NAOI, they could, consequently, be an additional tool in interpreting climaterelated processes in ecosystems. We therefore tested the differences of the impact of the indices on (1) local air and water temperature, (2) ice phenology and (3) the timing of the phytoplankton spring bloom in Lake Erken (Sweden), in order to improve the understanding of the variability and long-term changes of the lake variables.

\section{METHODS}

Lake Erken is a naturally meso-eutrophic lake in eastern Sweden $\left(59^{\circ} 25^{\prime} \mathrm{N}, 18^{\circ} 15^{\prime} \mathrm{E}\right)$ at $11 \mathrm{~m}$ above sea level with a surface area of $24 \mathrm{~km}^{2}$, a maximum depth of $21 \mathrm{~m}$, a mean depth of $9 \mathrm{~m}$ and a turnover time of $7 \mathrm{yr}$. The lake is always ice-covered in winter and the ice break-up, registered since 1954, occurs between March and the beginning of May. Water samples were taken $700 \mathrm{~m}$ offshore above the deepest part of the lake on a weekly basis during the ice-free period. From these water samples, chlorophyll a (chl a) was measured according to Ahlgren \& Ahlgren (1976). The timing of the spring bloom was defined as the day with maximum chl $a$ in spring. For this study, the volumeweighted averages of the measurements in 0 to $10 \mathrm{~m}$ water depths were used. The time series varied for different variables, covering the period 1954-1995, in which data from some years were missing.

Air temperature data close to Lake Erken were obtained from the Swedish Meteorological and Hydrological Institute since 1954, and the seasonal averages for winter (December-March) were calculated to compare with the winter values of the NAOI. The winter (December-March) NAOI was taken from the National Centre for Atmospheric Research, Boulder, CO, website (www.cgd.ucar.edu/ jhurrell/nao.html). This index is based on the difference of normalised sea-level pressures between Lisbon, Portugal, and Stykkisholmur/Reykjavik, Iceland. The monthly NAOI were taken from the Climate Prediction Center, Washington, DC, website (www.nnic.noaa.gov/data/ teledoc/nao.html).

The circulation indices for Scandinavia calculated by Chen (2000) were used as a measure for regional-scale circulation. The digital data file can be obtained from www.gvc.gu.se /ngeo/deliang/deliang.htm. The indices describe the westerly (zonal, $u$ ) and southerly (meridional, v) components of geostrophic wind, the combined wind speed $(V)$ and the total shear vorticity (ङ), computed on a monthly basis (for more details see Chen 2000).

Correlation analysis with the Pearson correlation coefficient (r) was employed to establish relationships between any variables of interest. If the correlations were affected by extreme points, such as the extreme

Table 1. Pearson correlation coefficients (r) between climate, physical and biotic variables in winter (December-March) and spring (March) at Lake Erken. Significance: ${ }^{*} p<0.05,{ }^{* *} p<0.01$ and ${ }^{* * *} p<0.001$. Coefficients in parenthesis show the correlations with the extreme years 1989 and 1990 excluded. n: number of observations

\begin{tabular}{|c|c|c|c|c|}
\hline & Winter NAOI & $\begin{array}{l}\text { Winter air temperature } \\
\qquad\left({ }^{\circ} \mathrm{C}\right)\end{array}$ & Spring NAOI & $\begin{array}{l}\text { Spring air temperature } \\
\left({ }^{\circ} \mathrm{C}\right)\end{array}$ \\
\hline $\begin{array}{l}\text { Ice cover period }(\mathrm{n}=36) \\
\text { (d) }\end{array}$ & $\begin{array}{l}-0.57^{* *} \\
\left(-0.48^{* *}\right)\end{array}$ & $\begin{array}{l}-0.73^{* * *} \\
\left(-0.66^{* * *}\right)\end{array}$ & $\begin{array}{l}-0.41^{*} \\
(-0.30)\end{array}$ & $\begin{array}{l}-0.59^{* *} \\
\left(-0.51^{* *}\right)\end{array}$ \\
\hline $\begin{array}{l}\text { Timing of ice break-up }(\mathrm{n}=37 \text { ) } \\
\text { (day of the year) }\end{array}$ & $\begin{array}{l}-0.57^{* *} \\
\left(-0.41^{*}\right)\end{array}$ & $\begin{array}{l}-0.73^{* * *} \\
\left(-0.66^{* * *}\right)\end{array}$ & $\begin{array}{l}-0.40^{*} \\
(-0.19)\end{array}$ & $\begin{array}{l}-0.59^{* *} \\
\left(-0.48^{* *}\right)\end{array}$ \\
\hline $\begin{array}{l}\text { Timing of spring bloom }(n=20) \\
\text { (day of the year) }\end{array}$ & -0.40 & -0.35 & $-0.50^{*}$ & $-0.64^{* *}$ \\
\hline
\end{tabular}


warm years 1989 and 1990, they were excluded to examine the influence of the extreme points on the general relationship. When applying all regional circulation indices, a stepwise multiple regression method was used. The number of predictors that is kept in the model is controlled by an F-test, with a significance level for a selected predictor set at $95 \%$. In this design, the multiple regression cannot be used to identify the individual role each index plays in an absolute sense, because of the weak interrelationship that exists. Therefore, the variance explained by the final regression is considered as a total explained variance in a statistical sense to be compared with that explained by the NAOI.

All statistical analyses were performed using Statistica $^{\circledR}$ (StatSoft 1996).

\section{NORTH ATLANTIC OSCILLATION}

The Swedish air temperature is strongly influenced by the large-scale atmospheric circulation, the NAO, with westerly winds and positive temperature anomalies, as already shown by Hurrell (1996) and Chen \& Hellström (1999). The present study confirms these finding, as the winter NAOI explained $46 \%$ of the local winter air temperature variation $(\mathrm{r}=0.68, \mathrm{p}<0.001, \mathrm{n}=$ 42). The local water temperature in winter was significantly correlated with neither the winter air temperature $(\mathrm{r}=0.53, \mathrm{p}<0.14, \mathrm{n}=12)$ nor the NAOI. During this period, the lake was ice- and snow-covered and, thus, insulated from the surrounding air.

The ice cover period in Lake Erken varied from 1 to 5 mo and the strongest relationship was found with the winter air temperature (Table 1). When the extreme years 1989 and 1990 were excluded (Table 1), the same pattern was apparent. These 2 years appeared to be very exceptional in northern Europe, i.e. extremely mild winters. However, the winter NAOI was still significantly correlated with the ice cover period (Table 1), i.e. a long ice cover period was associated with a negative NAOI.

The timing of ice break-up in Lake Erken varied from the beginning of March to the beginning of May. Early ice break-up dates were associated with high NAOI values. Again, the strongest correlation was found with air temperature, independent of whether the extreme years were included or not (Table 1). In general, the ice break-up in lakes is very sensitive to changes in winter air temperature (Anderson et al. 1996, Vavrus et al. 1996, Magnuson et al. 2000) and can be related to large-scale circulation (Livingstone 1999, Weyhenmeyer et al. 1999).

No significant correlation was found between the December-March climate variables and the timing of the spring bloom (Table 1). In order to understand the
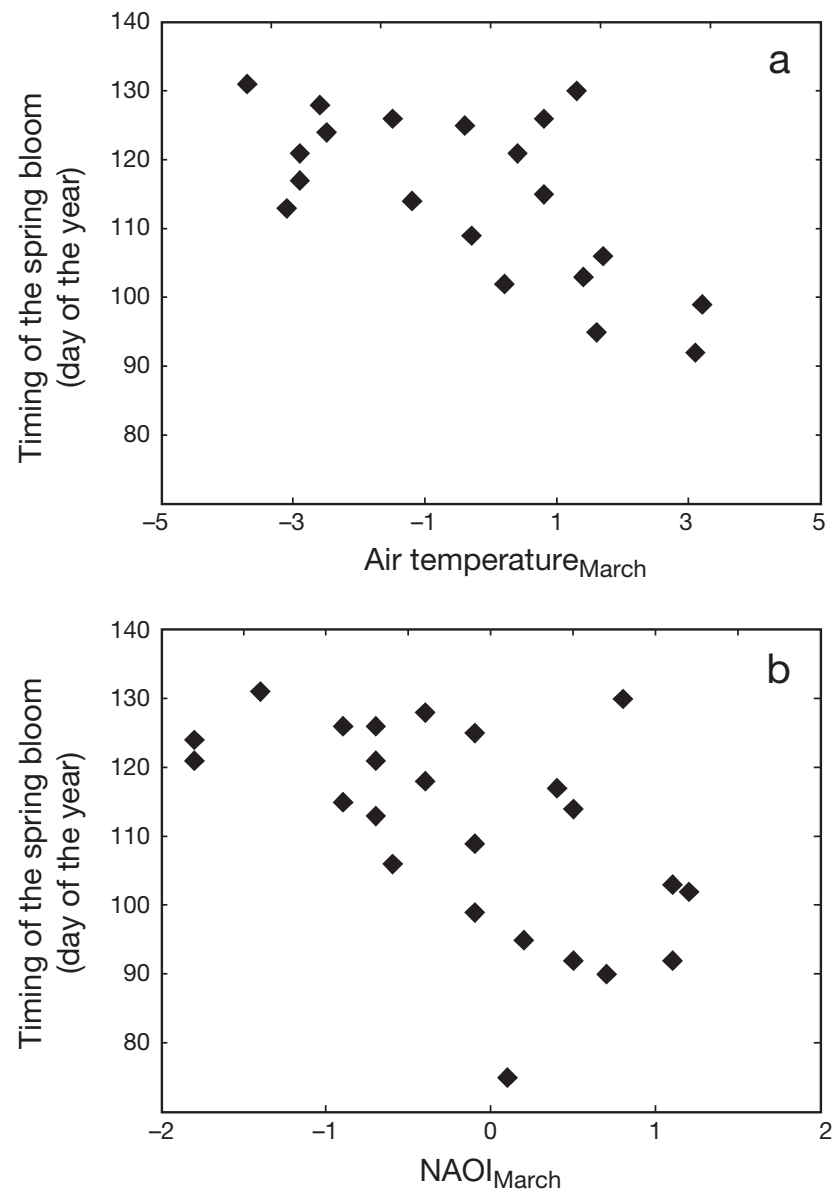

Fig. 1. Relationship between the timing of the spring bloom and (a) the air temperature in March and (b) the NAOI in March

year-to-year variability in the timing of the spring bloom, shorter timescales (i.e. monthly climate variables) were used. Only the March value of the NAOI was significantly correlated with the timing of the spring bloom, i.e. the timing of the phytoplankton spring bloom is mainly dependent on the conditions just before the peak. Comparable to the timing of ice break-up, the NAOI and air temperature had a corresponding influence on the timing of the spring bloom (Table 1, Fig. 1). The meteorological forcing of the winter period mainly acts on the ice phenology.

However, with no sufficiently cold winter conditions and lacking ice coverage, mean winter temperatures can act on the timing of the spring bloom, as shown by Müller-Navarra et al. (1997) and Güss et al. (2000). Winter and spring phytoplankton growth is generally known to be mainly light-limited (Reynolds 1989, Bleiker \& Schanz 1997), particularly in lakes with ice and snow cover (Nebaeus 1984). Our results reinforce previous findings that light conditions, indirectly influ- 
enced by the March climate, determine the snow on the ice and ice characteristics. Both parameters influence the light availability in the water for phytoplankton growth, which controls the timing of the spring bloom. Directly relating the timing of the ice break-up to the timing of the spring bloom did not result in a higher correlation coefficient (see Weyhenmeyer et al. 1999 for details).

\section{REGIONAL CIRCULATION INDICES}

Regional circulation indices were introduced in order to assess and compare the 2 circulation types. A stepwise multiple linear regression was used, which includes the indices as well as air and water temperatures, ice phenology and timing of the spring bloom.

In comparison to the NAOI, the regional atmospheric circulation indices can account for the variation of Swedish air temperature with a much higher explanatory power. Chen (2000) showed that a set of regional circulation indices explained $70 \%$ of the variation in the air temperature in January. The air temperature in March appears to be a crucial factor in the timing of both ice break-up and spring bloom in Lake Erken. Applying the multiple regression, $63 \%$ of the air temperature variation could be explained by the westerly wind components of February and March combined with a negative relation to the total vorticity in February (Table 2), whereas the NAOI in March only accounted for $48 \%$ of the variance $(\mathrm{r}=0.69, \mathrm{p}<0.0001$, $\mathrm{n}=42$ ).

This is expected, as the regional circulation may be more closely linked to local processes. The advantage of applying regional circulation indices is that their individual components can help to identify the underlying processes and crucial climate variables. In terms of the air temperature in March, we found that the westerly wind component was significant, which supports the high explanatory power of the NAOI in March. But also of importance here were the circulation in the preceding month (February) and especially the westerly wind component and the total vorticity (Table 2).

The ice cover period seems to be influenced by the whole winter period (Table 1), and therefore the December-March circulation set was applied. In that design, $56 \%$ of the variation in ice cover length can be explained by wind speed in January and December in combination with the westerly wind component in March. On the other hand, the winter NAOI only explained $32 \%$ of the variation.

Wind speed over Scandinavia is dictated by westerly winds derived from the Icelandic Low and the Azores High (Chen \& Hellström 1999). The speed of the westerly wind has a positive effect on temperature, which considerably shortens the period of ice cover. Additionally, the westerly wind in March influenced the period of ice cover, presumably due to its strong influence on the timing of ice break-up $(r=-0.55, \mathrm{p}<0.01$, $\mathrm{n}=32$ ).

Using the wind speed from January, February and March (Table 2), $73 \%$ of the variation in the timing of ice break-up could be explained, whereas the winter NAOI only explained $32 \%$ and winter air temperature $54 \%$. The timing of the ice break-up was mainly dependent on total wind speed from January to March (Table 2).

Table 2. Multiple regression on the dependent variables air temperature, ice cover period, timing of ice break-up and timing of phytoplankton spring bloom by applying the regional circulation indices. Listed are the explained variance $\left(\mathrm{r}^{2}\right)$, the $F$-ratio, and significance levels (p) for the complete regression model. Furthermore, estimates of the regression coefficient $(B)$ are given for the

intercept and each independent variable included in the model, together with significance levels $\left({ }^{*} \mathrm{p}<0.05,{ }^{* *} \mathrm{p}<0.01\right)$

\begin{tabular}{|c|c|c|c|c|c|c|}
\hline Dependent variable & $\mathrm{r}^{2}$ & $F$ & $\mathrm{p}$ & Intercept & Variable included & $B$ \\
\hline Air temperature in March & 0.631 & 24.43 & $<0.0001$ & -2.95 & $\begin{array}{l}u_{\mathrm{Mar}} \\
u_{\mathrm{Feb}} \\
\varsigma_{\mathrm{Feb}}\end{array}$ & $\begin{array}{c}0.63^{* * *} \\
0.25^{*} \\
-0.22^{*}\end{array}$ \\
\hline Ice cover period & 0.564 & 18.71 & $<0.0001$ & 178.99 & $\begin{array}{l}V_{\text {Jan }} \\
u_{\text {Mar }} \\
V_{\text {Dec }}\end{array}$ & $\begin{array}{l}-0.49^{* * *} \\
-0.41^{* *} \\
-0.26^{*}\end{array}$ \\
\hline Timing of ice break-up & 0.729 & 33.37 & $<0.0001$ & 153.43 & $\begin{array}{l}V_{\mathrm{Feb}} \\
V_{\text {Jan }} \\
V_{\mathrm{Mar}}\end{array}$ & $\begin{array}{l}-0.43^{* *} \\
-0.48^{* * *} \\
-0.34^{* *}\end{array}$ \\
\hline Timing of spring bloom & 0.595 & 10.36 & 0.0005 & 122.43 & $\begin{array}{l}u_{\text {Mar }} \\
\zeta_{\text {Jan }} \\
V_{\text {Jan }}\end{array}$ & $\begin{array}{c}-0.54^{* *} \\
0.40^{*} \\
-0.37^{*}\end{array}$ \\
\hline
\end{tabular}


Remarkably, the wind speed in January already predefines the ice conditions during winter. This is also reflected by the fact that the timing of ice break-up is more closely correlated to the winter NAOI than to the NAOI in March (Table 1).

Using the westerly wind in March, the total vorticity and the southern wind component in January, $60 \%$ of the variation in the timing of the spring bloom could be explained. The NAOI and air temperature in March only explained 25 and $41 \%$, respectively.

The crucial importance of the March conditions resembles the findings discussed above. Additionally, the regional indices reveal an equally important impact of the January conditions, which so far remains unclear and deserves further investigation.

\section{SUMMARY AND CONCLUSION}

Our results clearly indicate the influence of the large-scale and regional circulation on local lake processes. Furthermore, we could demonstrate that regional atmospheric circulation influenced the length of the ice cover period and the timing of both the ice break-up and phytoplankton spring bloom more powerfully than the large-scale NAO. Moreover, the set of regional indices offers the possibility of a better understanding of the underlying processes.

The findings show that regional indices have a large potential to explain climate-driven responses in lakes, with a relatively simple method. One of the main reasons why the NAOI is employed in an expanded body of work is because this index is freely available and easy to use. The same can now be stated for the regional indices, but with the advantage that their explanatory power is higher. It was demonstrated that the main variables affecting the lake in winter are wind speed and the zonal geostrophic wind, both parameters influencing the positive temperature anomaly in winter.

Moreover, the analysis of the influence of the NAOI on long-term ice extent and ice break-up data reveals that this impact is not stationary over time (Livingstone 1999, Omstedt \& Chen 2001), whereas the application of regional circulation indices has already been found to have a stable impact over time on the Baltic sea ice extent (Omstedt \& Chen 2001). Additionally, the regional index is based on monthly grid pressure data, which can easily be predicted by climate models (Omstedt \& Chen 2001), whereas the predictive power for the NAOI is relatively low (Osborn et al. 1999). Consequently, when studying climate-driven responses on ecosystems, regional atmospheric indices might be very useful tools in addition to large-scale atmospheric circulation indices.
Acknowledgements. This study was funded by the European Union Environment and Climate project REFLECT (Response of European Freshwater Lakes to Environmental and Climate Change; contract ENV4-CT97-0453). We are thankful to everyone involved in sampling, analysing and establishing the database at Lake Erken. Gesa Weyhenmeyer, Kurt Pettersson, Helmut Hillebrand, Stephanie Blenckner, Don Pierson and 3 anonymous reviewers gave constructive comments on the manuscript.

\section{LITERATURE CITED}

Ahlgren I, Ahlgren G (1976) Analytical methods for water chemistry. Rep no. 80, Institute of Limnology, Uppsala University

Anderson WL, Robertson DM, Magnuson JJ (1996) Evidence of recent warming and El Nino-related variations in ice breakup of Wisconsin lakes. Limnol Oceanogr 41:815-821

Bleiker W, Schanz F (1997) Light climate as the key factor controlling the spring dynamics of phytoplankton in Lake Zurich. Aquat Sci 59:135-157

Blenckner T, Hillebrand H (2002) North Atlantic Oscillation signatures in aqutic and terrestrial ecosystems - a metaanalysis. Global Change Biol 8:203-212

Blenckner T, Pettersson K, Padisak J (2002) Lake plankton as tracer to discover climate signals. Verh Int Verein Limnol 28: (in press)

Chen D (2000) A monthly circulation climatology for Sweden and its application to a winter temperature case study. Int J Climatol 20:1067-1076

Chen D, Hellström C (1999) The influence of the North Atlantic Oscillation on the regional temperature variability in Sweden: spatial and temporal variations. Tellus 51A: 505-516

Forchhammer MC, Post E, Stenseth NC (1998) Breeding phenology and climate. Nature 391:29-30

Fromentin JM, Planque B (1996) Calanus and environment in the eastern North Atlantic. II. Influence of the North Atlantic Oscillation on C. finmarchicus and C. helgolandicus. Mar Ecol Prog Ser 134:111-118

George DG (2000) The impact of regional-scale changes in the weather on the long-term dynamics of Eudiaptomus and Daphnia in Esthwaite Water, Cumbria. Freshw Biol 45:111-121

Gerten D, Adrian R (2000) Climate-driven changes in spring plankton dynamics and the sensitivity of shallow polymictic lakes to the North Atlantic Oscillation. Limnol Oceanogr 45:1058-1066

Gerten D, Adrian R (2001) Differences in the persistency of the North Atlantic Oscillation signal among lakes. Limnol Oceanogr 46:448-455

Güss S, Albrecht D, Krambeck HJ, Mueller-Navarra DC, Mumm H (2000) Impact of weather on a lake ecosystem, assessed by cyclo-stationary MCCA of long-term observations. Ecology 81:1720-1735

Hagberg J, Tunberg BG (2000) Studies on the covariation between physical factors and the long-term variation of the marine soft bottom macrofauna in western Sweden. Estuar Coast Shelf Sci 50:373-385

Hartley S, Keables MJ (1998) Synoptic associations of winter climate and snowfall variability in New England, USA, 1950-1992. Int J Climatol 18:281-298

Hurrell JW (1995) Decadal trends in the North Atlantic Oscillation: regional temperature and precipitation. Science 269:676-679

Hurrell JW (1996) Influence of variations in extratropical win- 
tertime teleconnections on Northern Hemisphere temperature. Geophys Res Lett 23:665-668

Kidson JW (1994) Relationship of New Zealand daily and monthly weather patters to synoptic weather types. Int J Climatol 14:723-737

Lamb HH (1950) Types and spells of weather around the year in the British Isles. Q J R Meterol Soc 76:393-438

Livingstone D (1999) Ice-break up on southern Lake Baikal and its relationship to local and regional air temperatures in Sibiria and the North Atlantic Oscillation. Limnol Oceanogr 44:1486-1497

Magnuson JJ, Robertson DM, Benson BJ, Wynne RH and 10 others (2000) Historical trends in lake and river ice cover in the Northern Hemisphere. Science 289:1743-1746

Meehl GA, Boer GL, Covey C, Latif M, Stouffer RJ (2000) The coupled model inter comparison project (CMIP). Bull Am Meteorol Soc 81:313-318

Müller-Navarra DC, Güss S, von Storch H (1997) Interannual variability of seasonal succession events in a temperate lake to its relation to temperature variability. Global Change Biol 3:429-438

Nebaeus M (1984) Algal water-blooms under ice-cover. Verh Int Verein Limnol 22:719-724

Omstedt A, Chen D (2001) Influence of atmospheric circulation on the maximum ice extent in the Baltic Sea. J Geophys Res 106:4493-4500

Editorial responsibility: Hans von Storch, Geesthacht, Germany
Osborn TJ, Briffa KR, Tett SFB, Jones PD, Trigo RM (1999) Evaluation of the North Atlantic Oscillation as simulated by a coupled climate model. Clim Dyn 15: 685-702

Plaut G, Ghil M, Vautard R (1995) Interannual and interdecadal variability in 335 years of Central England temperatures. Science 268:710-713

Post E, Stenseth NC (1998) Large-scale climatic fluctuation and population dynamics of moose and white-tailed deer. J Anim Ecol 67:537-543

Post E, Stenseth NC (1999) Climatic variability, plant phenology, and northern ungulates. Ecology 80:1322-1339

Post E, Peterson RO, Stenseth NC, McLaren BE (1999) Ecosystem consequences of wolf behavioural response to climate. Nature 401:905-907

Reynolds CS (1989) Physical determinations of phytoplankton succession. In: Sommer U (ed) Plankton succession on plankton communities. Springer, Berlin, p 9-56

StatSoft (1996) Statistica. StatSoft, Tulsa

Vavrus SJ, Wymne RH, Foley JA (1996) Measuring the sensitivity of southern Wisconsin lake ice to climate variations and lake depth using a numerical model. Limnol Oceanogr 41:822-831

Weyhenmeyer G, Blenckner T, Pettersson K (1999) Changes of the plankton spring outburst related to the North Atlantic Oscillation. Limnol Oceanogr 44:1788-1792

Submitted: July 19, 2001; Accepted: May 15, 2002

Proofs received from author(s): August 16, 2002 